\title{
SIMULATION MODEL FOR SEAWATER DISTILLATION BY SOLAR ENERGY
}

\author{
Gamea G.R.*, Taha .A.T**., Qaid Y.A.***
}

\begin{abstract}
Mathematical model was developed to simulate and predict the thermal behavior of the solar still which used direct solar energy for distillation of seawater. The simulation results obtained from this model was compared with the measured data to evaluate the present model. The main results of this research showed that there are slight differences between the measured and predicted values of the elements studied, which is resultant from changing of some factors affecting that are considered constants in the model such as the sky clearance, wind velocity and the salt concentration in the water in the basin of solar still. It can be concluded that the present model can be used to estimate the average total solar radiation and the thermal behavior of the solar still in any area with consideration the geographical location.
\end{abstract}

\section{INTRODUCTION}

W ater is fundamental to life and a prerequisite to all living things, and water is a renewable resource but it is also finite. Human has been dependent on rivers, lakes and underground water reservoirs for fresh water requirements. However, rapid industrial growth and the expansion of agricultural together with the population explosion all over the world and enhanced living standards have resulted in a large escalation of demand for fresh water and a decline in the amount of water available per person. The only nearly inexhaustible sources of water are the oceans. Their main drawback is their high salinity and thus would be appropriate for solving the problem of shortage of fresh water by desalination of sea water.

Many areas in Egypt and other countries in the world suffer from lack of fresh water which hinders the development of these areas, despite the availability of saline water and high solar radiation intensity.

\footnotetext{
*Assoc. Prof. of Agriculture Engineering Faculty of Agriculture Minofiya University. ** Lecturer of Agriculture Engineering Faculty of Agriculture Minofiya University. ***Assoc. lecturer of Agriculture Engineering Faculty of Agriculture Ibb University Yemen Republic.
} 
Furthermore, most of developing countries do not have sufficient meteorological data to evaluate if the solar radiation enough to meet the solar desalination. Solar desalination units are gradually emerging as a successful renewable energy systems of producing fresh water.

Over a billion people worldwide lack access to sufficient water of good quality. (Samee. et. al. 2007). The large escalation of demand for fresh water in the Middle East and North Africa due to a rather low efficiency of water distribution and use, and also due to the continuous growth of population. (Trieb and Steinhagenthe,2008).

Drinking water of acceptable quality has become a scarce commodity. This leads to an increasing interest in desalination technologies by using a thermal energy source. The thermal energy may be obtained from a conventional fossil-fuel source or non-conventional source such as solar energy. Solar-powered desalination technologies are suitable and may be the only technically and economically competitive alternative for small desalination capacities to provide drinking water in remote areas where access to fuel, electricity, and technical expertise is not available. Most desalination plants worldwide currently use energy conventional sources with associated carbon dioxide emissions contributing to global climate change. For each $1 \mathrm{~m}^{3}$ of water generated in an reverse osmosis (RO) plant using fossil fuel (oil), about $3 \mathrm{~kg}$ of $\mathrm{CO}_{2}$ is produced (Fiorenza et al., 2003). Desalination processes require significant quantities of energy. It is estimated that the capacity of desalinated water systems in year 2000 was about 25 million $\mathrm{m}^{3} /$ day. It has been estimated that the production of 25 million $\mathrm{m}^{3} /$ day requires 230 million tons of oil per year .(Kalogirou, 2004). The main problem of seawater desalination is an intensive consumer of fossil fuels, so seems completely logical used the solar energy for desalination.(Blanco et,al 2008). Each square kilometer of land in the Middle East and North Africa receives every year an amount of solar energy that is equivalent to 1.5 million barrels of crude oil up to now, this tremendous energy resource is completely untapped.(Trieb et al (2009).

The solar radiation data are a fundamental input for solar energy applications . The data should be contemporary, reliable and readily available for design, optimization and performance evaluation of solar 
technologies for any particular geographical location. But, for many developing countries, solar-radiation measurements are not easily available because of the expensive measuring equipment and techniques required. Therefore, it is necessary to develop methods to estimate the solar radiation on the basis of the more readily available meteorological data Taha(2010). The majority of the models developed for the prediction of solar radiation are based on existing climatic-parameters. Bulut and Buyukalaca (2007). Simulations are powerful tools for the modeling, design, prediction of performance and research and development Kalogirou, (2004). The solar energy can be studied in two ways, the experimental study and the numerical simulation study. Simulations (using the graphical programming language Simulink.) are numerical experiments and can give some kinds of thermal performance information as can physical experiments. Shen et al (2008).

The aim of this investigation was to develop a simulation mathematical model to predicting of the thermal behavior of the solar still which used direct solar energy to desalination of saline water.

\section{MATERIALS AND METHODS}

\section{Mathematical model:}

The seawater desalination by solar energy model consists of two submodels, solar radiation model and solar still model.

\subsection{Solar radiation model:}

To simulate this model the solar radiation mathematical equations were written in the language of MATLAB/simulink.

The extraterrestrial radiation on the plane normal to radiation on the $n t h$ day of the year is estimated as follow: (Stine and Harrigan, 1985).

$$
I_{\text {on }}=I_{s c}[1+0.034 \cos (360 n / 365.25)] \quad\left[\mathrm{Wm}^{-2}\right]
$$

To estimate the solar radiation was received by each of the water in the basin and the basin liner of the solar still as horizontal surfaces the following equations were used:

$$
I_{G}=I_{D}+I_{d}
$$

$\left[\mathrm{Wm}^{-2}\right]$

The direct radiation is estimated as: (Hottel, 1976)

$$
I_{D}=I_{o n} \tau_{D} \cos \theta_{z} \quad\left[\mathrm{Wm}^{-2}\right]
$$


PROCESS ENGINEERING

The diffuse radiation is estimated as:

$$
I_{d}=I_{o n} \tau_{d} \cos \theta_{z} \quad\left[\mathrm{Wm}^{-2}\right]
$$

To calculate the solar radiation was received by the tilted glazing cover and vertical back wall of the solar still, the following equations were used:

$$
I_{G t}=I_{D t}+I_{d t}+I_{r t}
$$

$\left[\mathrm{Wm}^{-2}\right]$

According to (Taha,2003) the direct radiation for an inclined surface $\left(\mathrm{I}_{\mathrm{Dt}}\right)$ can be calculated as follow:

$$
I_{D t}=\left(I_{G}-I_{d}\right) \cos \theta
$$

$\left[\mathrm{Wm}^{-2}\right]$

According to Temps and Coulson (1977) the amount of diffuse radiation and reflected radiation estimating as follow:

$$
\begin{aligned}
& I_{d t}=I_{d}[(1+\cos \beta) / 2]\left[1+\sin ^{3}(\beta / 2)\left[1+\cos ^{2} \theta \sin \theta_{z}\right] \quad\left[\mathrm{Wm}^{-2}\right](7)\right. \\
& \left.I_{r t}=I_{D} \partial[(1-\cos \beta) / 2]+I_{d} \partial[(1-\cos \beta) / 2]\left[1+\sin ^{2}\left(\theta_{z} / 2\right)\right] \cos \gamma\right]
\end{aligned}
$$

Then, these equations were solved by an iterative procedure in the computer by MATLAB program to obtain each of; the global radiation received on a horizontal (solar still basin liner and water surface), the global radiation received on tilted (solar still cover) and global radiation received on vertical (solar still back-wall). These outputs were used as inputs in solar still model.

\subsection{Solar still model:}

The solar still model was designed for calculating heat and mass flux. This sub-model is composed of several elements, which include thermal equilibrium for each of the glass cover, salt water, the pelvic floor, back wall and indoor air in addition to solar still productivity. The state of the important variables are determined by energy and mass balances. The energy balance of this solar still was simulated, the various terms of the energy balance will be described. The energy balance for every part of the solar still was formulated as the sum of the fluxes at the part should be equal zero Taha et. al, (2009). 
PROCESS ENGINEERING

For the thermal balance of glazing cover:

$$
I_{G t} \alpha_{g}+q_{r(w-g)}+q_{r(b w-g)}+q_{c(\text { air }-g)}+q_{\text {conds(air-g) }}+q_{r(g-s)}+q_{c(g-a)}=0
$$

For the water mass in solar still basin:

$$
I_{G} \tau_{g} \alpha_{w}+q_{c(b-w)}+q_{r(w-b w)}+q_{e(w-a i r)}+q_{r(g-w)}+q_{c(a i r-w)}=0
$$

For the basin liner:

$$
I_{G} \tau_{g} \tau_{w} \alpha_{b}+q_{c(b-w)}+q_{c o n(b-a)}=0
$$

For the back-wall:

$$
I_{G v} \tau_{g} \alpha_{b w}+q_{c(b w-a i r)}+q_{c o n(b w-a)}+q_{r(b w-g)}+q_{r(b w-w)}=0
$$

For the internal solar still air:

$$
q_{c(w-a i r)}+q_{c(b w-a i r)}+q_{c(\text { air-g })}+q_{e(w-a i r)}+q_{c o n d s(a i r-g)}=0
$$

To calculate the temperature of the solar still elements (glass cover, water, basin liner, back wall and internal air) the following differential equation was used (Taha, 2003):

$$
T=\frac{1}{\rho C_{p} x} \int_{t=0}^{t=y}\left(q_{\text {in }}-q_{\text {out }}\right) d t
$$

The radiation heat flux calculated as follow (Strauch 1985), (Balkomb1992) and (Al-Said et al 1994).

$$
\begin{array}{ll}
q_{r(w-g)}=\varepsilon_{w} \varepsilon_{g} \sigma\left(T^{4}{ }_{w}-T_{g}^{4}\right)[(1-\cos \beta) / 2] & {\left[\mathrm{Wm}^{-2}\right]} \\
q_{r(b w-g)}=\varepsilon_{b w} \varepsilon_{g} \sigma\left(T_{b w}^{4}-T_{g}^{4}\right)\{[1-\cos (90-\beta)] / 2\} & {\left[\mathrm{Wm}^{-2}\right]} \\
q_{r(b w-w)}=\varepsilon_{b w} \varepsilon_{w} \sigma\left(T_{b w}^{4}-T^{4}{ }_{w}\right)[(1-\cos 90) / 2] & {\left[\mathrm{Wm}^{-2}\right]} \\
q_{r(g-s)}=\varepsilon_{g} \sigma\left(T_{g}^{4}-T_{s}^{4}\right) & {\left[\mathrm{Wm}^{-2}\right]}
\end{array}
$$


PROCESS ENGINEERING

Where:

$\mathrm{T}$ the part temperature $\mathrm{K}^{\circ}$

The convective heat flux between a solid surfaces of the solar still and the adjacent liquid or gas is given by the following general equation:

$$
q_{c}=h_{c} \cdot A \cdot \Delta T
$$

$\left[\mathrm{Wm}^{-2}\right]$

The value of conductive heat flux through a plane wall of solar still was be expressed as follows:

$$
q_{\text {con }}=K \cdot A \cdot \Delta T / x \quad\left[\mathrm{Wm}^{-2}\right]
$$

The mass of water steam carried by air from water surface to the internal glazing cover then condensation on it. According to (AlSaid et al, 1994) the rates of heat transfer by vaporization/condensation estimated as follow:

$$
\begin{aligned}
& q_{e}=0.0061\left\{\left[T_{w}-T_{g} \mathbb{\Pi}\left(P_{w}-P_{g}\right) /\left(0.265-p_{w}\right)\right]\left[T_{w}+273\right]\right\}^{1 / 3} \\
& \left\{P_{w}-P_{g}\right\} \lambda
\end{aligned}
$$

Finally the Solar still productivity was be expressed as follows (Cappelletti, 2002):

$$
M=q_{e} / \lambda_{g} \quad\left(\mathrm{kgd}^{-1}\right)
$$

These equations were solved in the computer by MATLAB program to obtain each of; cover temperature, water temperature, basin bottom temperature, inner air temperature and solar still production. The inputs and outputs of solar radiation model and solar still model were illustrated as flow diagram in figure (1).The simulation was run after build the model using MATLAB/Simulink program and input hourly ambient temperature from measured data. This model was applied during 28,31 August and 1 September 2010 .

\section{Solar still set-up:}

The conventional solar still as shown in figure (2) was constructed in the Agricultural Engineering Department at El-Minofiya University (Shebin El-Kom city) at Latitude angle of $30^{\circ} .54^{\prime} \mathrm{N}$ and31E. The water basin of the solar still was $1 \mathrm{X} 0.50 \mathrm{~m}$ which created a net area of $0.5 \mathrm{~m}^{2}$, and 0.10 $\mathrm{m}$ in depth. The basin of the solar still and the back-wall are fabricated using galvanized iron sheet of $2 \mathrm{~mm}$ thickness, painted dark black dye 
and insulated by $3 \mathrm{~cm}$ thickness of foam with $0.03 \mathrm{~W} / \mathrm{m} \mathrm{K} \mathrm{K}^{\mathrm{o}}$ thermal conductivity. The cover was made up of $3 \mathrm{~mm}$ thick simple window glass, The solar still cover was tilted at an angle of $30^{\circ} .54^{\prime}$ from the horizontal plane toward south. The fresh water is collected in a channel fixed at the lower end of the glass cover and is taken out through a plastic pipe. The whole system completely airtight lock.

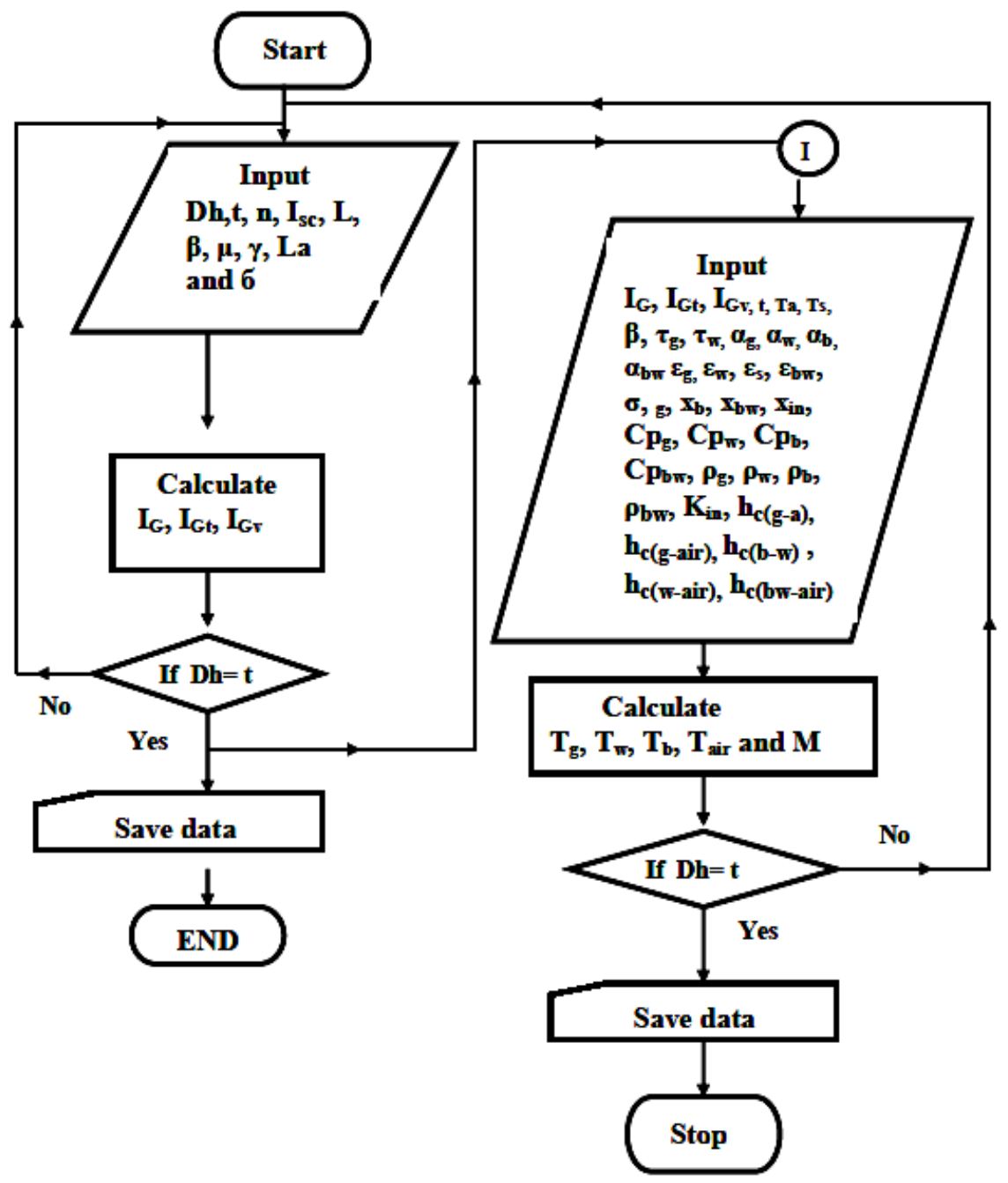

Fig.(1) Mathematical model flow diagram. 


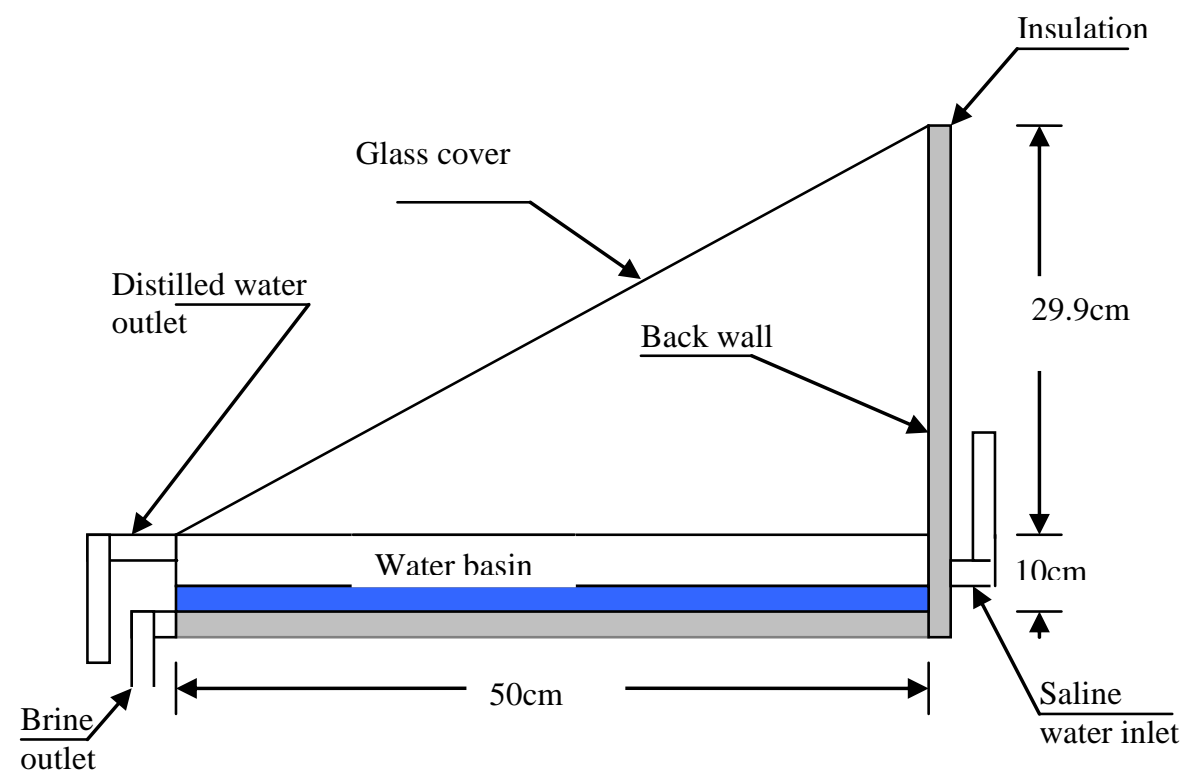

Figure(2) Schematic diagram of solar still.

\section{Measurments:}

The pyranometer model PSP was used to measure the solar radiation intensity $\left(\mathrm{Wm}^{-2}\right)$. The thermocouples wires which connected to temperature sensors (LM35) were used to measure the temperature of each of the ambient air, glass cover, the water in the basin, basin bottom, back wall and internal air. These positions were connected to data acquisition device (Lab-Jack U3) which was connected to the computer to record the data by special program(Profilab-Expert 0.4).Simulink of MATLAB computer program was used to carry out simulation model.

Measurements were taken during 28,31 August and 1 September 2010 then, simulation data were compared with measurements.

\section{RESULTS AND DISCUSSION}

The comparison between measured and simulated results is very important in order to check out how far the simulated results are from the measured ones. To investigate the model's ability to predict and describe each of hourly solar radiation intensity and thermal performance of the solar still. 
(a)

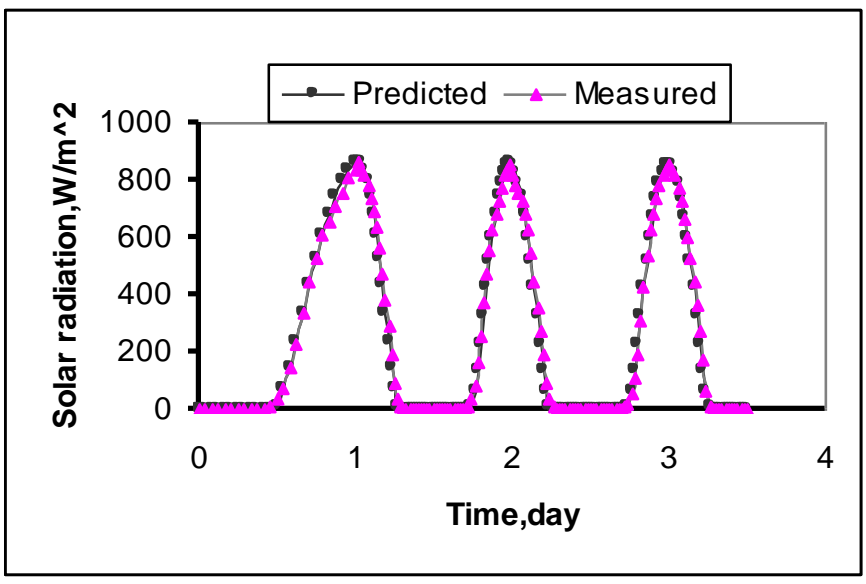

(b)
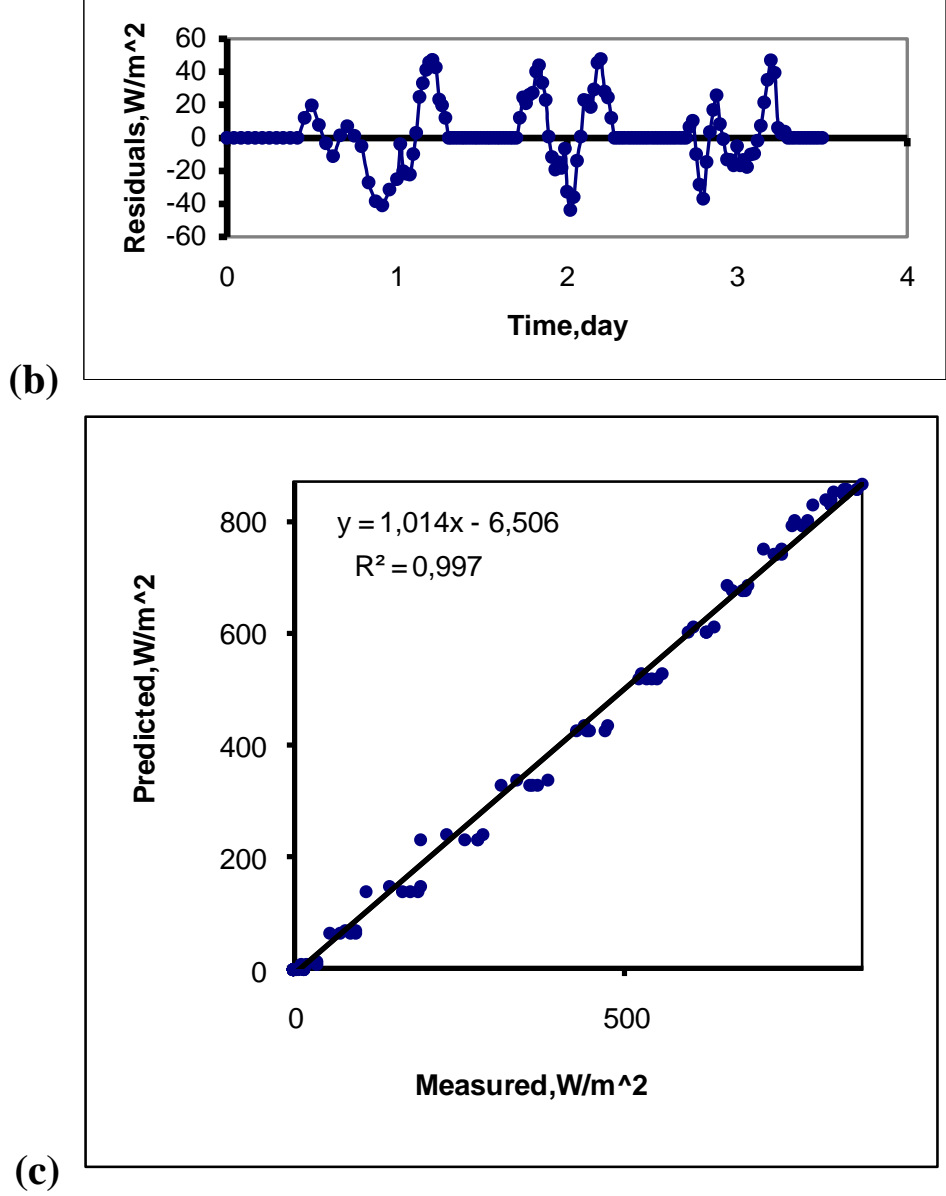

Figure(3) Predicted and measured solar radiation for the period studied (28,31Aug. and 1Sept.).

(a)values, (b) residuals and (c) the correlation. 


\section{Solar radiation:}

Figure (3) shows the results of total solar radiation on horizontal surface measured and predicted in period studied. As shown in Fig. $(3, a)$ the model gave high agreement with experimental results and the simulated solar radiation followed the same trends as that measured one but with some slight variations in some of the values. Fig. $(3, b)$ represents the differences between the measured and the predicted values of the solar radiation for the simulation period, where it can be seen that the higher difference occurred in the late afternoon of the day, medium difference in before noon and the lower difference in the middle of the day. The measured hourly solar radiation was plotted versus the predicted from simulation model as shown in Fig.(3,c) which indicated to high correlation coefficient $\left(\mathrm{R}^{2}=0.9972\right)$ between the predicted and measured values .

\section{Solar still:}

Fig.(4) represent the comparison between predicted and measured of the solar still glass cover temperature during a studied period .

As shown in fig.(4,a), it can be seen that a good agreement between the simulated and the experimental result of the solar still glass cover temperature during a studied period and the simulated glass temperature followed the same trends as that measured one with some variations. Figure $(4, b)$ shows the differences between simulated and measured glass temperature which ranged between 1 to $3 \mathrm{C}^{\circ}$. While, Fig. $(4, \mathrm{c})$ shows the correlation coefficient between predicted and measured solar still glass cover temperature which indicated to high correlation coefficient $\left(R^{2}=0.9828\right)$ between the predicted and measured values.

Figure (5) shows the results of salty water temperature measured and predicted for the simulation period. As shown in Figure $(5, a)$ the model gave the high estimate and have the smallest errors for the water temperature values. The figure shows also that the simulated water temperature followed the same trends as that measured one but with some slight variations in some of the values. 
a)
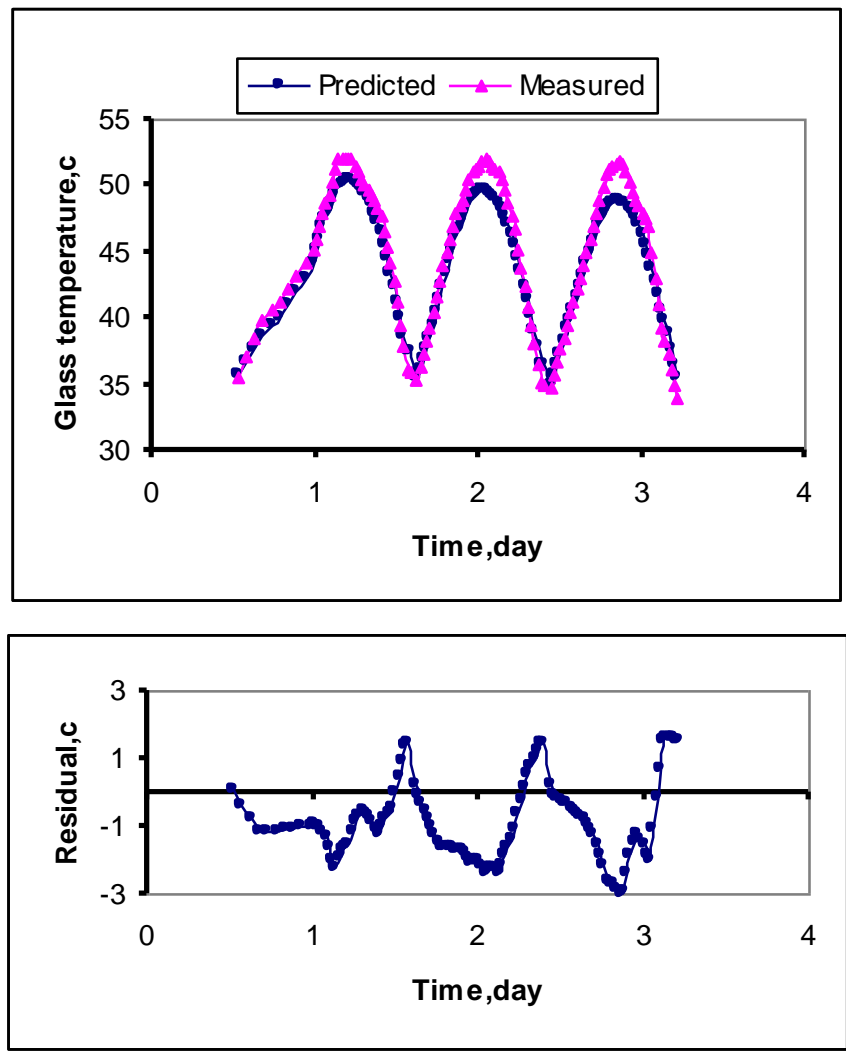

b)

c)

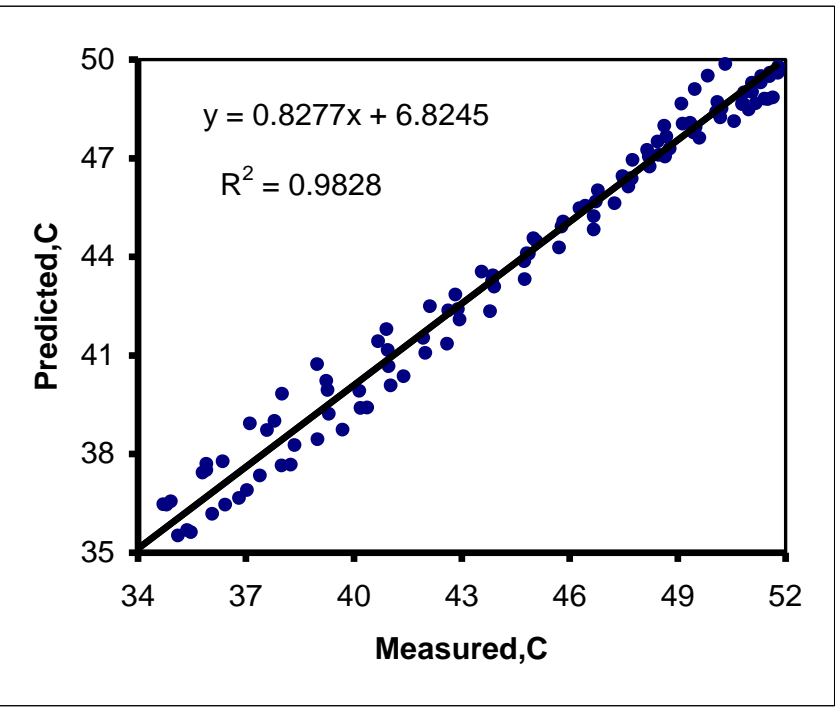

Fig.(4) Predicted and measured solar still glass cover temperature for the period studied (28,31Aug. and 1Sep.)

(a)values,(b) residuals and (c) the correlation. 


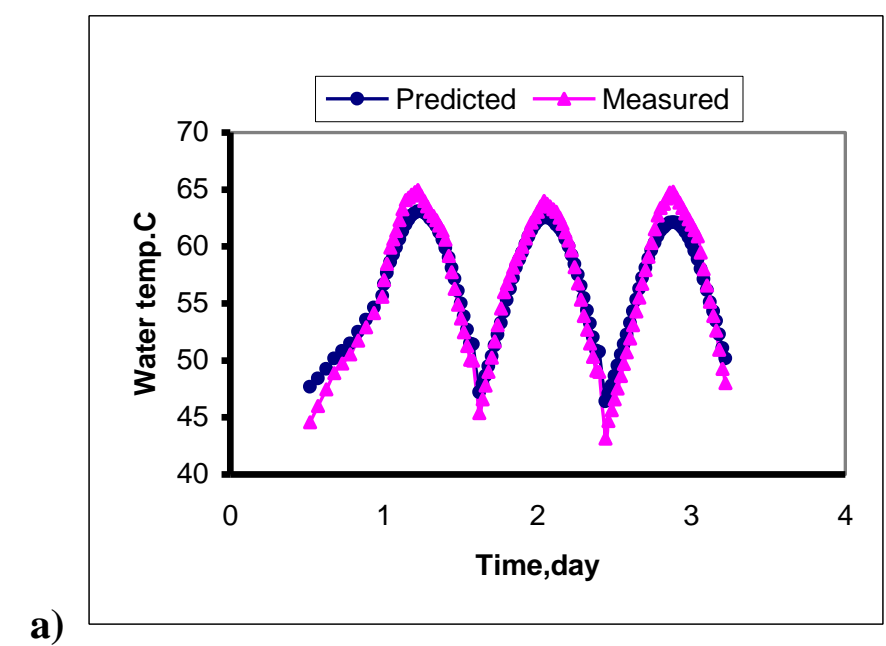

a)

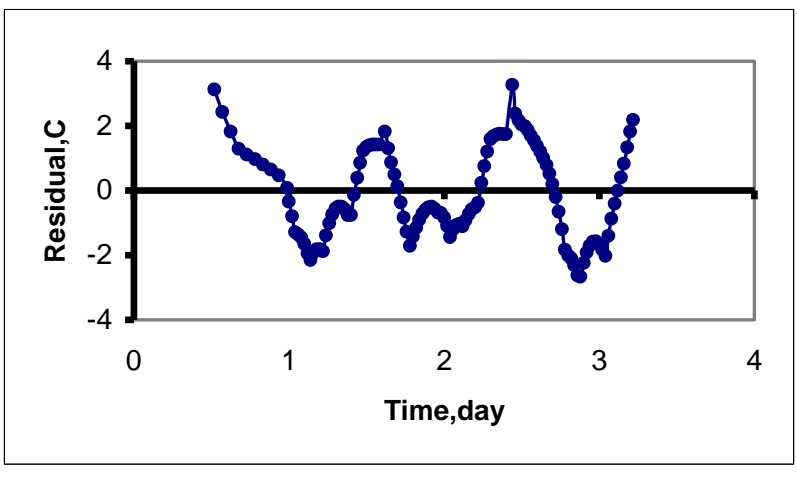

b)

c)

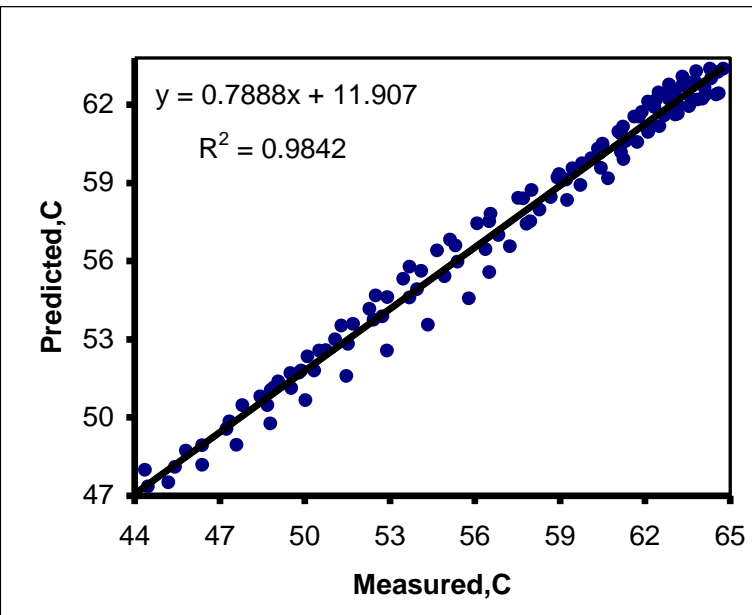

Fig.(5) Predicted and measured salty water temperature for the period studied (28,31Aug. and 1Sep.).

(a)values,(b) residuals and (c) the correlation. 
Fig.(5,b) represents the differences between the measured and the predicted values of the water temperature for the simulation period which ranged between 0 to $3.5 \mathrm{C}^{\circ}$, where it can be seen that the higher difference occurred in the morning of the three studied days and early afternoon of the third day. As shown in Fig. $(5, \mathrm{c})$ the measured water temperature was plotted versus the predicted from simulation model which indicated to high correlation coefficient $\left(R^{2}=0.9842\right)$ between the predicted and measured values .

Fig.(6) represent the comparison between predicted and measured of the solar still basin liner temperature. As shown in fig. $(6, a)$, there is a good agreement between the simulated and the experimental result of the solar still basin liner temperature during a studied period and the simulated basin liner temperature followed the same trends as that measured one with some variations. Fig. $(6, b)$ shows the differences between the measured and the predicted values of the basin liner temperature for the simulation period where found that the predicted values higher than measured values. This increasing was ranged between 1 to $4 \mathrm{C}^{\circ}$, where it can be seen that the higher difference occurred in the morning and late afternoon of the three studied days. While, Fig. (6,c) shows the correlation coefficient between predicted and measured solar still basin liner temperature which indicated to high correlation coefficient $\left(\mathrm{R}^{2}=\right.$ 0.9865).

Fig.(7) represent the comparison between predicted and measured of the solar still internal air temperature during a studied period .

As shown in fig. $(7, a)$, it can be seen that a high agreement had been found between the simulated and the experimental result of the solar still internal air temperature and the simulated internal air temperature followed the same trends as that measured one with some variations. The figure $(7, b)$ shows the differences between simulated and measured solar still internal air temperature which ranged between 0 to $3 \mathrm{C}^{\circ}$ where it can be seen that the higher difference occurred in the early afternoon of the day, while, lower difference occurred before noon and in the late afternoon of the day. 
a)
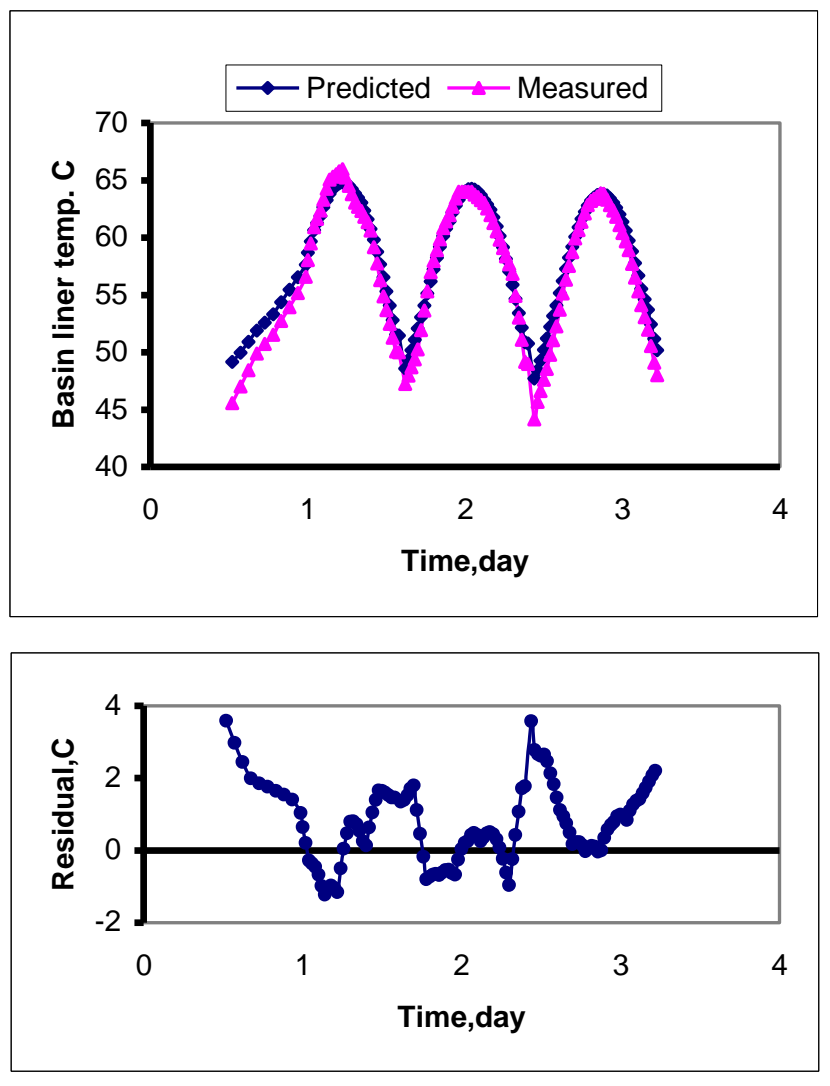

b)

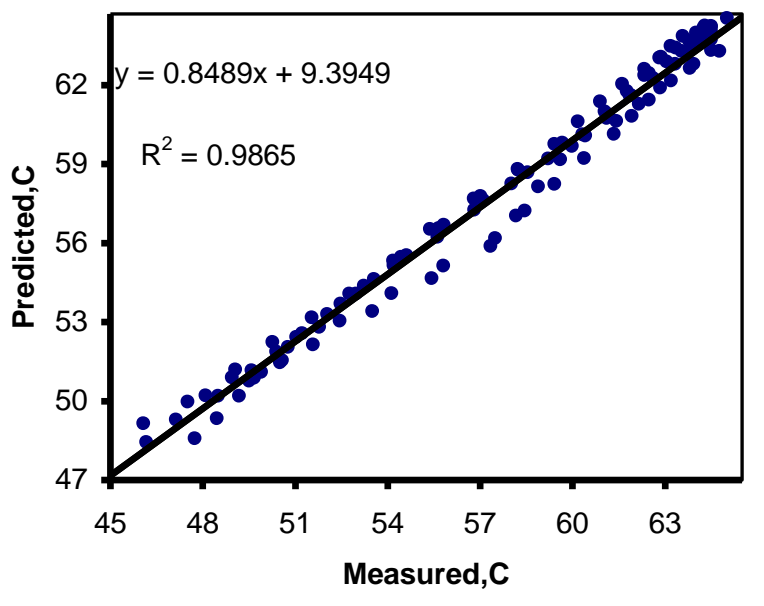

c)

Fig.(6) Predicted and measured solar still basin liner temperature for the period studied $(28,31 \mathrm{Aug}$. and 1Sep.).

(a)values,(b) residuals and (c) the correlation. 
a)
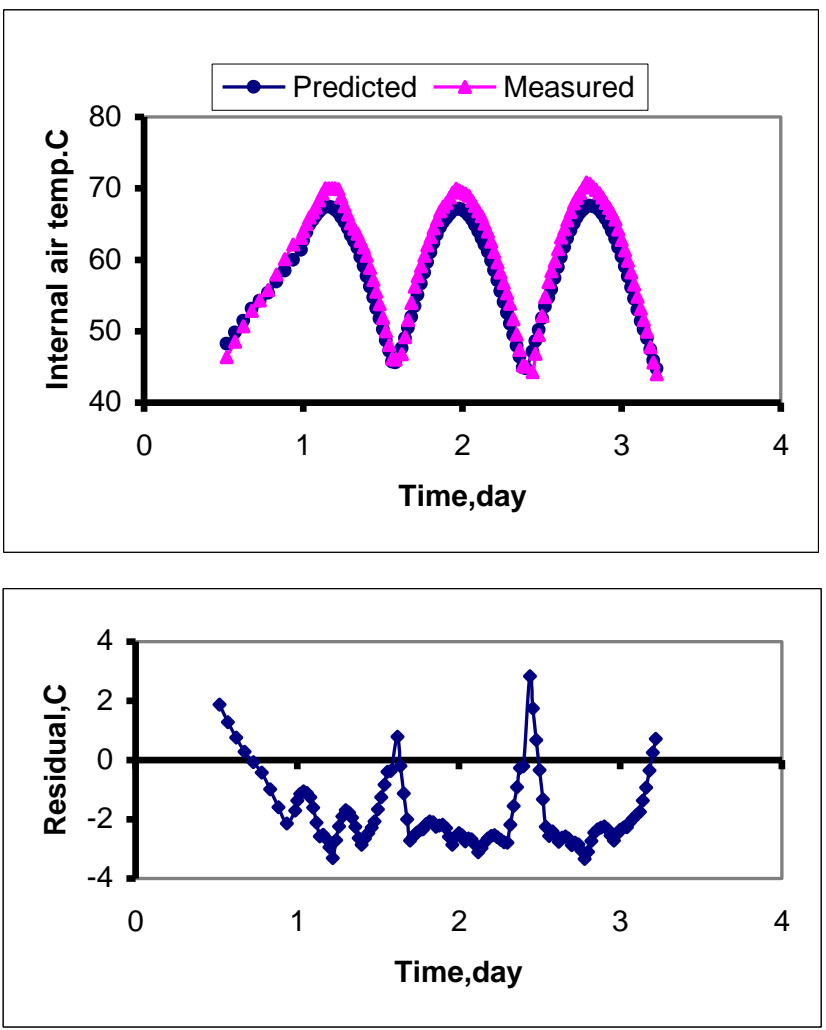

b)

c)

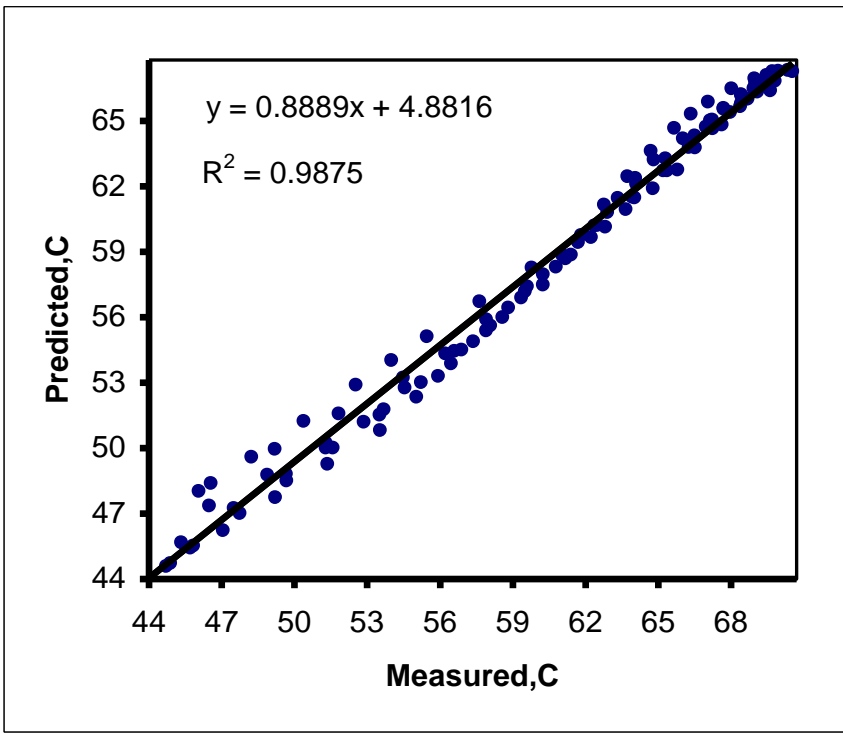

Fig.(7) Predicted and measured solar still internal air temperature for the period studied (28,31Aug. and 1Sep.). (a)values,(b) residuals and (c) the correlation. 
While, Fig. $(7, \mathrm{c})$ shows the correlation coefficient between predicted and measured solar still internal air temperature which indicated to high correlation coefficient $\left(\mathrm{R}^{2}=0.9875\right)$.

Fig.(8) represent the comparison between predicted and measured of the solar still distilled water productivity during a studied period. As shown in fig. $(8, a)$, the solar still simulated productivity followed the same trends as that measured one with some variations. While, the figure $(8, b)$ shows the differences between simulated and measured solar still productivity which ranged between 0 to $0.2 \mathrm{Kg}\left(200 \mathrm{~cm}^{3}\right)$ where it can be seen that the higher difference occurred at noon and early afternoon of the studied days, while, lower difference occurred at morning, before noon and in the late afternoon of the day.Fig. $(8, c)$ shows the correlation coefficient between predicted and measured solar still productivity which indicated to high correlation coefficient $\left(\mathrm{R}^{2}=0.9821\right)$.

\section{CONCLUSIONS}

Comparison the model output data with the measured data revealed that the model provides predictions in good agreement with the measured data with there are slight differences between the measured and predicted values of the elements studied, which is resultant from changing of some factors affecting that are considered constants in the model such as the sky clearance, wind velocity and the salt concentration in the water in the basin of solar still.. Therefore, the overall advantage shows that the developed model described very well the thermal performance of solar still.

The developed mathematical model is useful for predicting the total solar radiation received on the horizontal surfaces and thermal behavior of the solar still including glazing cover temperature, water temperature, basin bottom temperature, internal air temperature and solar still productivity of distilled water with consideration the geographical location. 
a)
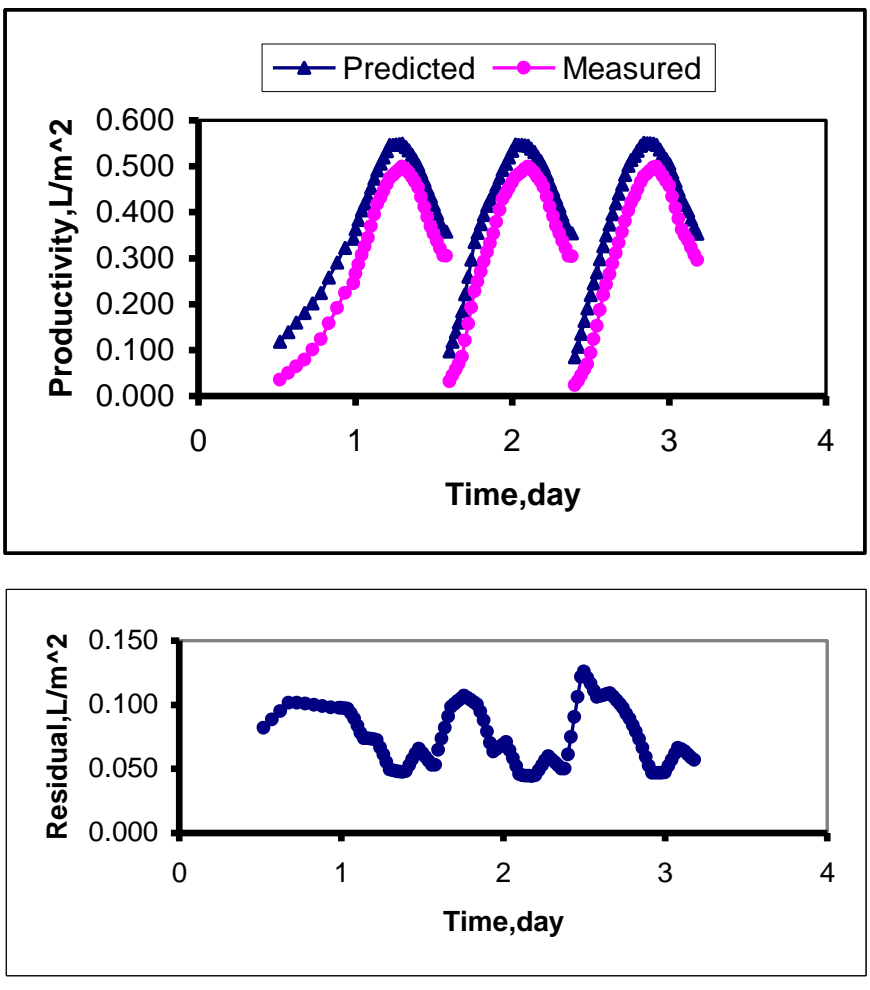

b)

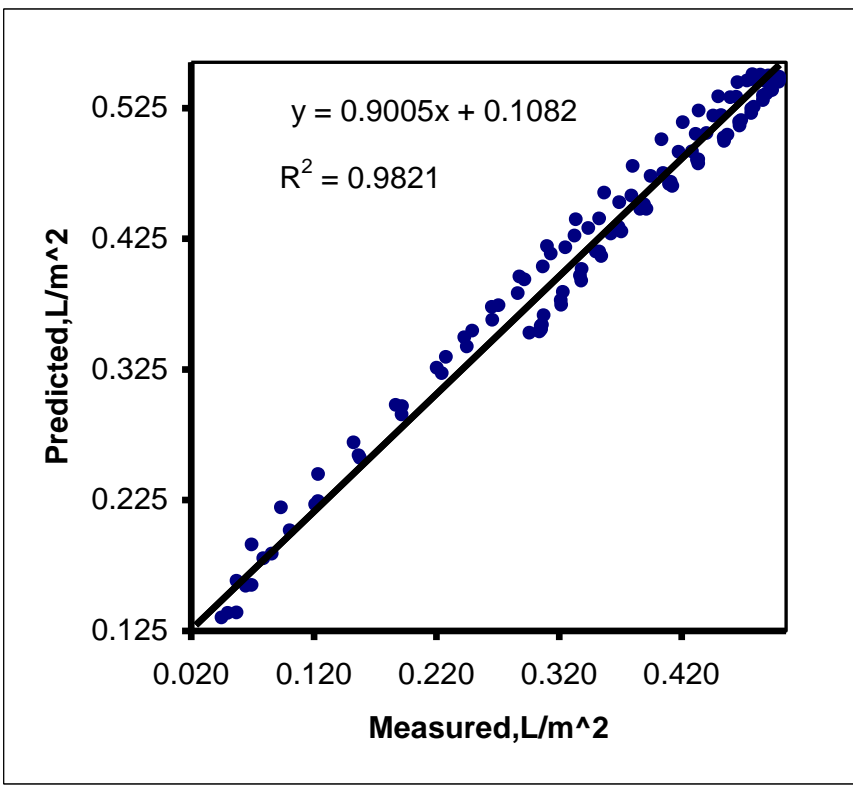

Fig.(8) Predicted and measured solar still productivity of distillated water for the period studied (28,31Aug. and 1Sep.).

(a)values,(b) residuals and (c) the correlation. 
PROCESS ENGINEERING

\section{REFERENCES}

Balcome, J. D.(1992) Passive solar buildings. The MIT press. Cambridge, Massachusetts, London, England.

Blanco J. , Malato S. , Ibanez P. F., Alarcon D. , Gernjak W. and Maldonado M.I. (2008) Review of feasible solar energy applications to water processes. Renewable and Sustainable Energy Reviews, 595:1-9.

Bulut H. and Buyukalaca O.(2007) Simple model for the generation of global solar-radiation data in Turkey. Applied Energy 84 : 477-491.

Cappelletti G. M. (2002) An experiment with a plastic solar still. Desalination 142: 221-227.

Fiorenza, G., Sharma, V.K., Braccio, G., (2003). Techno-economic evaluation of a solar powered water desalination plant. Energy Conservation and Management 44, 2217-2240.

Hottel H. C. (1976) A simple model for estimating the transmittance of direct solar radiation through clear atmospheres. Solar Energy, 18(2): 129-134.

Kalogirou S. A. (2004) Solar thermal collectors and applications. Progress in Energy and Combustion Science 30 : 231-295.

Samee M. A., Mirza U. K. , Majeed T.and Ahmad N. (2007) Design and performance of a simple single basin solar still. Renewable and Sustainable Energy Reviews, 11 : 543-549.

Shen C., He Y. L., Liu Y. W. and Tao W. Q. (2008) Modelling and simulation of solar radiation data processing with Simulink, Simulation Modelling Practice and Theory $16: 721-735$.

Stine W. B. and Harrigan R. W. (1985) Solar energy fundamentals and design. Wiely and sons.

Strauch K.H.(1985) Geschlossene Gewachshaussysteme mit integrierter solarer wasserentsalzungsanlage fur aride gebiete. Gartenbautechnische Informationen 22, Universitat Hannover.

Taha A.T. (2010) Estimation of Hourly Global Solar Radiation in Egypt Using Mathematical Model.Misr,J. Ag. Eng. 27(4):233-247.

Taha A. (2003) Simulation model of energy fluxes in passive solar greenhouses with a concrete north-wall. Unpublished $\mathrm{Ph}$. Thesis. Hanover University, Germany.

Taha .A.T., Eissa. A.H., Gamea G.R. and Hidarh . H.M. (2009) Simulation model of flat plate solar collector performance. 
Proceeding of the First Scientific Conference for Marketing the Applied University Research "Academic Research for the Service of Industry ". Minoufiya University,Shebin El-Kom, Egypt

Temps R. S. and Coulson K. L. (1977) Solar radiation incident upon slopes of different orientations. Solar Energy, 19(3):179-263.

Trieb F. and Steinhagen H. M(2008) Concentrating solar power for seawater desalination in the Middle East and North Africa. Desalination $220: 165-183$.

Trieb F. , Steinhagen H. M., Kern J. , Scharfe J. Kabariti M. and Al Taher A.(2009) Technologies for large scale seawater desalination using concentrated solar radiation. Desalination $235: 33-43$.

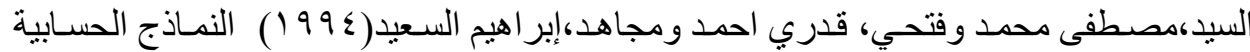

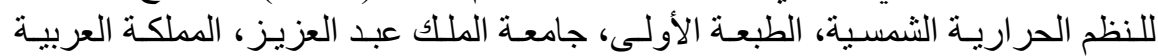

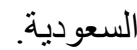

NOMENCLATURES

\begin{tabular}{|c|c|}
\hline 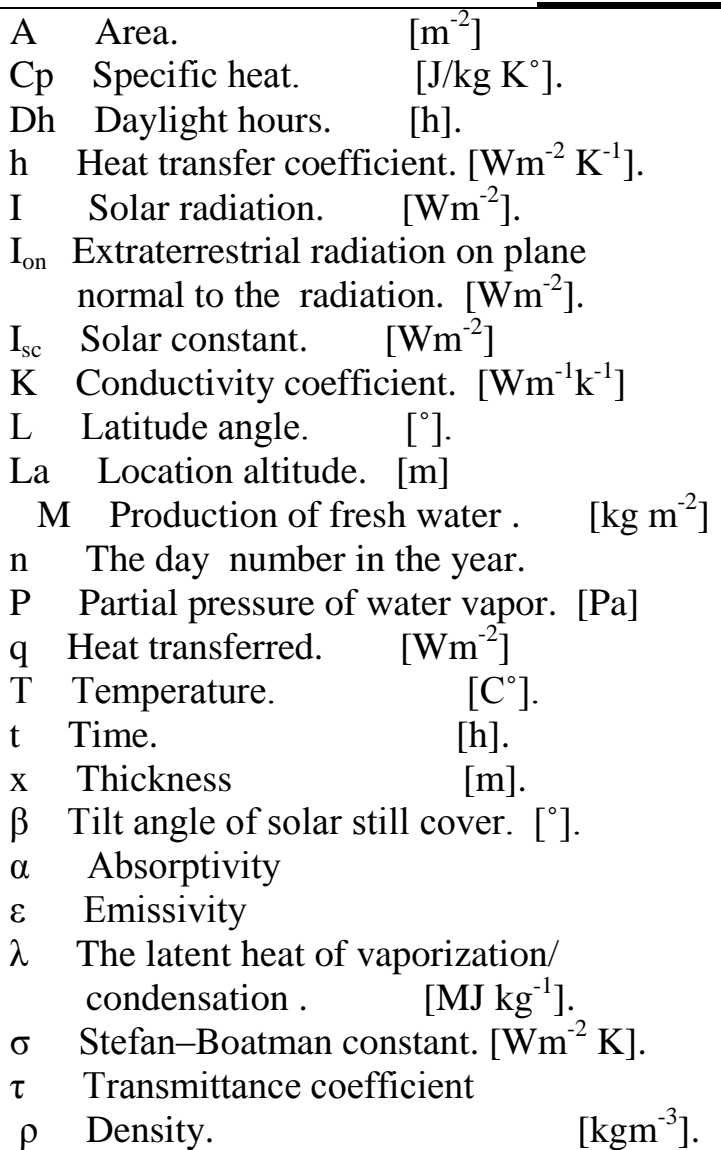 & $\begin{array}{ll}\theta & \text { The incidence angle. }\left[{ }^{\circ}\right] \\
\theta_{\mathrm{z}} & \text { Zenith angle. }\left[^{\circ}\right] \\
\gamma & \text { Surface solar azimuth angle. }\left[{ }^{\circ}\right] \\
\partial & \text { Ground surface reflectance. } \\
\text { Subscripts: } \\
\text { a } & \text { Ambient } \\
\text { air } & \text { Solar still inner air } \\
\mathrm{b} & \text { Basin liner } \\
\text { bw } & \text { The solar still back-wall } \\
\mathrm{c} & \text { Convective } \\
\text { con } & \text { Conductive } \\
\text { conds } & \text { Condensation } \\
\mathrm{D} & \text { Direct radiation on a horizontal } \\
\mathrm{d} & \text { Diffuse radiation on a horizontal. } \\
\mathrm{Dt} & \text { Direct radiation on tilted surfaces. } \\
\mathrm{dt} & \text { Diffuse radiation on tilted surfaces. } \\
\mathrm{e} & \text { Evaporative } \\
\mathrm{G} & \text { Global radiation on a horizontal } \\
\mathrm{I}_{\mathrm{Gt}} & \text { Global radiation on tilted surfaces. } \\
\mathrm{Gv} & \text { Global radiation on a vertical. } \\
\mathrm{g} & \text { Glazing cover. } \\
\mathrm{Ins} & \text { Insulation. } \\
\mathrm{r} & \text { Radiative } \\
\mathrm{rt} & \text { The reflected radiation. } \\
\mathrm{s} & \text { Sky } \\
\mathrm{w} & \text { Water }\end{array}$ \\
\hline
\end{tabular}




\section{الملخص العربي}

\section{نموذج محاكاة لتحلية مياه البحر بالطاقة الثمسية}

\section{جمال رشاد جامع*، أحمد توفيق طه***، يحيى عبد الجليل قائد**** *}

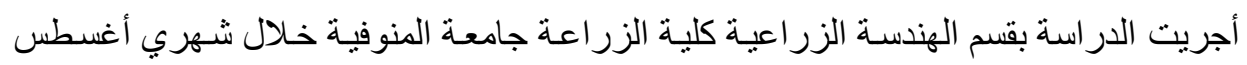

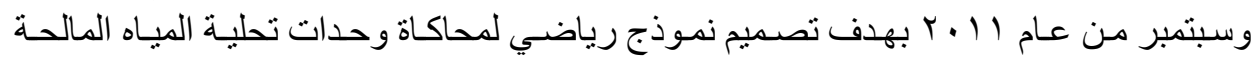

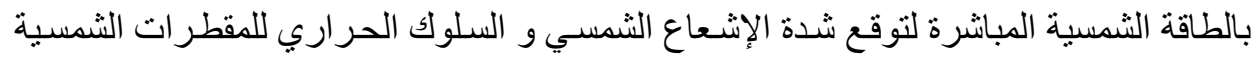

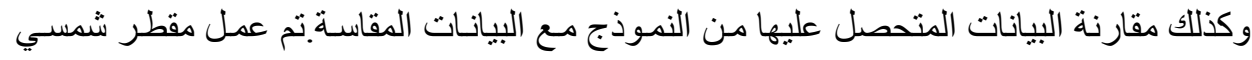

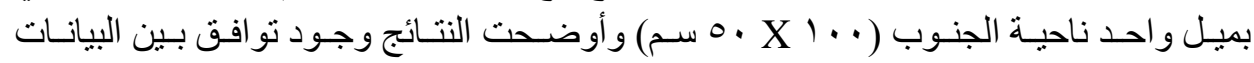

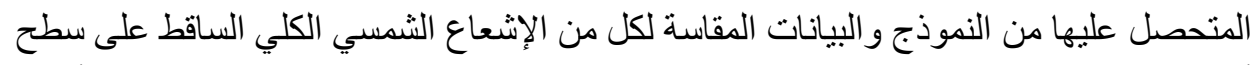

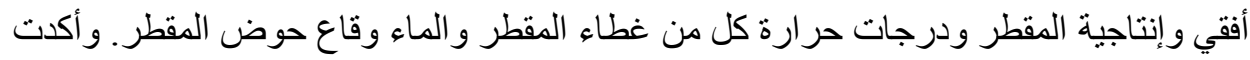

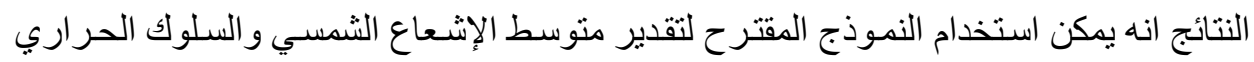
للمقطر ات الثمسية في أي مكان مع الأخذ في الاعتبار المتغير ات المتأثرة بالموقع الجغر افي. 